\title{
Withdrawal or reduction of the dietary vitamin premix on bone parameters of broiler chickens in two rearing systems
}

\author{
H. Moravej ${ }^{1}$, M. Alahyari-Shahrasb ${ }^{2 \#}$, M.R. Baghani ${ }^{3}$ \& M. Shivazad ${ }^{1}$ \\ ${ }^{1}$ Department of Animal Science, Faculty of Agriculture and Natural Resources, University of Tehran, Karaj/Iran \\ ${ }^{2}$ Young Researchers Club, Abarkooh Branch, Islamic Azad University, Abarkooh, Yazd/Iran \\ ${ }^{3}$ Department of Mechanical Engineering, Agriculture and Natural Resources, Pardis, University of Tehran, Karaj/Iran \\ Copyright resides with the authors in terms of the Creative Commons Attribution 2.5 South African Licence. \\ See: http://creativecommons.org/licenses/by/2.5/za \\ Condition of use: The user may copy, distribute, transmit and adapt the work, but must recognise the authors and the South African Journal \\ of Animal Science.
}

\begin{abstract}
This study was conducted to compare the withdrawal or reduction of the vitamin premix (VP) from broiler diets at between days 29 and 42 of age on the characteristics of leg bones of the broilers in a battery cage (Trial 1) and a floor (Trial 2) rearing system. Seven experimental diets were formulated, based on wheat and barley, and consisted of four replicates per treatment. The metatarsus bone was used for measuring biomechanical bone characteristics, and alkaline phosphatase (ALP) activity and calcium concentrations blood serum to assess vitamin $\mathrm{D}_{3}$ status. The results of the first trial showed that there were no significant differences in body weight, strength of metatarsus bone and contents of ash, $\mathrm{Ca}$ and $\mathrm{P}$ in the toe with reduction or withdrawal of the vitamin premix from the diets during days 29 - 35. However, after $36-42$ days there were significant differences for these parameters between the treatment without the vitamin premix (T1) and the other treatments. At 29 - 35 days and 36 - 42 days there were significant differences for ALP activity between T1 and the other treatments. The results of Trial 2 showed that the reduction in the vitamin premix and withdrawal at d 29 did not impair body weight, bone parameters and blood concentrations during the final growth period of the broilers. Finally, the results of the present study indicate that in the battery cage system it is possible to reduce the level of the dietary vitamin premix during the finisher period, but withdrawal can negatively affect body weight and bone parameters of broiler chickens, while in the floor system it is possible to withdrawal VP from broilers' finisher diets.
\end{abstract}

Keywords: Alkaline phosphatase, ash, broilers, calcium, bone strength

\# Corresponding author: majid.alahyari@ut.ac.ir

\section{Introduction}

Although dietary vitamin and mineral requirements for birds are periodically redefined, some aspects of these requirements are continuously questioned. A deficiency of vitamins requires relatively long periods to manifest in clinical signs. However, the withdrawal of vitamin supplements in grower diets has been evaluated in the last few years as a way of reducing the cost of broiler chicken production (Skinner et al., 1992). Deyhim \& Teeter (1993) reported that the removal of both vitamins and trace elements from the broiler diet when reaching the age of 28 to 49 days reduced weight gain (WG) and feed efficiency (FE). The removal of trace elements alone was not detrimental, while the removal of vitamins reduced WG, FE and breast yield. Therefore, these experiments were conducted to evaluate the removal of vitamins and/or trace elements from broiler diets during the finisher period. Patel et al. (1997) showed that a 7-d removal of supplemental vitamins and trace elements from the broiler diet consisting of corn-soybean meal from d 35 to d 42 post hatching decreased weight gain in three broiler strains. Maiorka et al. (2002) indicated that a withdrawal of vitamins and trace elements at $42 \mathrm{~d}$ did not impair feed intake or weight gain, but significantly affected feed conversion ratio. Khajali et al. (2006) reported that a 14-d withdrawal (42 - 56) of a vitamin or trace element mix did not influence the performance of broilers. Alahyari-Shahrasb et al. (2011) reported that the withdrawal of a vitamin premix at $29 \mathrm{~d}$ did not influence the immune system of broilers. Ogunwole 
et al. (2011) showed that the removal of supplemental vitamin-mineral premixes from starter and finisher corn-soybean meal diets decreased weight gain in the Arbor Acre broiler strain. In these studies there were no reports about the effect of withdrawal or reduction of vitamin supplements on the characteristics of the leg bones, because vitamin $\mathrm{D}$ is a calcitropic hormone involved in Ca absorption in the intestine; it is widely used as a feed supplement (Rath et al., 2000). Vitamin D has a major regulatory role in bone metabolism and bone strength (NRC, 1994). Occasional field rickets in certain flocks of birds can produce a major disaster owing to poor mineralization and weak bones, which can be traced to a vitamin D deficiency or impaired vitamin D metabolism (Rath et al., 2004). Besides vitamin D, vitamins $\mathrm{B}_{6}$, C, and $\mathrm{K}$ are integral to bone health because of their involvement in the synthesis of matrix constituents, such as collagen and osteocalcin, and formation of collagen cross-links (Weber, 1999). Vitamin $\mathrm{B}_{6}$ (pyridoxine) deficiency affects collagen cross-links and bone mechanical properties (Masse et al., 1996). Market-age poultry often suffer from lameness and bone deformities, which can cause bone breakage during catching and transportation, which can create problems during processing (Rath et al., 2000). Overall, the economic cost associated with bone problems in poultry can add up to several hundred million dollars a year. There are several reports about vitamin premix withdrawal in broiler diets based on maize and rearing floor system, but founded on the following causes, it seems necessary to study the withdrawal or reduction of vitamin supplements in finisher diets of broilers based on wheat and barley in the battery cage system:

1. World maize prices are unstable and producers have a propensity to use wheat and barley instead of maize in the diet of broiler chickens;

2. There are differences among the vitamin contents of wheat, barley and maize;

3. There is a lack of reports about the effect of withdrawal or reduction of vitamin supplements on the characteristics of leg bones from the point of view of catching and transportation and the creation of problems during processing;

4. Birds in cages require more dietary vitamins than those in floor housing because of less opportunity for coprophagy.

Therefore, this study was carried out to evaluate the effects of reduction or withdrawal of the vitamin supplements from broiler diets during the finisher period on characteristics of leg bones in two rearing systems: battery cage and floor rearing.

\section{Material and Methods}

The care and housing of the broilers in the study was conducted in accordance with the guidelines of the Canadian Council on Animal Care (Olfert et al., 1993). Two trials were conducted to evaluate the reduction or withdrawal of the vitamin premix during the final phase of broiler chicken growth (between 29 $\mathrm{d}$ and $42 \mathrm{~d}$ of age). Trial 1 evaluated the effect of a reduction or withdrawal of the vitamin premix ( $29-42 \mathrm{~d}$ ) in the battery cage system and Trial 2 assessed the effect of reduction or withdrawal of the vitamin premix from finisher period ( $29-42 \mathrm{~d}$ ) in the floor system. The average initial body weight of chicks in each pen was $42 \mathrm{~g}$. Room temperature was kept at $34{ }^{\circ} \mathrm{C}$ during the first three days of the trial and then reduced gradually according to age until it reached $22{ }^{\circ} \mathrm{C}$ at $21 \mathrm{~d}$. The light was continuous during the first three days, and then the lighting regimen was $23 \mathrm{~h} / \mathrm{d}$.

The diets in all treatments were based on wheat and barley with different levels of a vitamin premix, as follows: T1) without vitamin premix during 29 - 42 days; T2) 33\% vitamin premix during 29 - 42 days; T3) $33 \%$ vitamin premix during 29 - 35 days and without it during days 36 - 42; T4) 66\% vitamin premix during 29 - 42 days; T5) 66\% vitamin premix during 29 - 35 days and without it during days 36 - 42; T6) 100\% vitamin premix during 29 - 42 days and T7) $100 \%$ vitamin premix during 29 - 35 days and without it during days $36-42$ (Table 2). During the finisher period, weight gain was measured at the end of each week. The ingredient composition of the experimental diets and the nutrient composition are shown in Table 1. The research was carried out in March-April 2010 at the Department of Animal Science, Faculty of Agriculture and Natural Resources, University of Tehran, Karaj, Iran.

Feed in mash form and water were available ad libitum. Prior to formulation, all major dietary ingredients were analysed for nitrogen-corrected apparent metabolisable energy (AMEn), amino acid (AA) profiles according to prediction formula of the NRC (1994), crude protein (CP), crude fibre (CF) and ether extract (EE) as described by AOAC (2000). 
A total of 112 male broiler chicks with similar body weight were distributed into battery cages in a completely randomized design at $23 \mathrm{~d}$ of age and fed similar grower diets up to $28 \mathrm{~d}$ with seven treatments and four repetitions per treatment of four birds each. Initial body weights were similar in all cages (1125 \pm $11.1 \mathrm{~g})$.

Table 1 Composition of the starter and grower diets used in the pre-experimental trials 1 and 2

\begin{tabular}{lcc}
\hline Feedstuff & $\begin{array}{c}\text { Starter diet } \\
(\mathrm{g} / \mathrm{kg})\end{array}$ & $\begin{array}{c}\text { Grower diet } \\
(\mathrm{g} / \mathrm{kg})\end{array}$ \\
\hline Wheat & 340 & 351.4 \\
Barley & 320 & 300 \\
Soybean meal $(440 \mathrm{~g} / \mathrm{kg} \mathrm{CP})$ & 239.8 & 269.3 \\
Gluten meal & 56.2 & 25.1 \\
Soya oil & 10.3 & 17.8 \\
Oyster shell & 13.0 & 12.9 \\
Dicalcium phosphate & 10.5 & 10.5 \\
Vitamin premix & 2.5 & 2.5 \\
Mineral premix & 2.5 \\
Sodium chloride & 2.5 & 2.5 \\
DL-Methionine & 2.8 & 2.8 \\
L-Lysine-HCl & 0.6 & 2.1 \\
Enzyme & 1.3 & 2.6 \\
Calculated composition & 0.5 & 0.5 \\
ME (MJ/kg) & & \\
Analysed crude protein $(\mathrm{g} / \mathrm{kg})$ & 11.70 & 11.90 \\
Met (g/kg) & 208 & 200 \\
Met + Cys (g/kg) & 3.9 & 5.1 \\
Lys (g/kg) & 7.6 & 8.6 \\
Sodium & 9.9 & 11.2 \\
Calcium & 1.5 & 1.5 \\
Phosphorus available & 8.1 & 8.1 \\
& 4.1 & 4.1
\end{tabular}

${ }^{1} 2.5 \mathrm{~kg}$ of vitamin premix containing $2700 \mathrm{mg}$ retinal; $400 \mathrm{mg}$ calcidiol; $18 \mathrm{~g}$ tocopheryl acetate; 2000 mg menadione; $1800 \mathrm{mg}$ thiamine; $6600 \mathrm{mg}$ riboflavin; $10 \mathrm{~g}$ niacin; $30 \mathrm{~g}$ calcium pantothenate; $3 \mathrm{~g}$ pyridoxine; $1 \mathrm{~g}$ folic acid; $15 \mathrm{mg}$ cyanocobalamin; $250 \mathrm{~g}$ choline chloride; $100 \mathrm{mg}$ biotin.

${ }^{2} 2.5 \mathrm{~kg}$ of trace mineral premix containing $100 \mathrm{~g} \mathrm{Mn} ; 50 \mathrm{~g} \mathrm{Fe} ; 100 \mathrm{~g} \mathrm{Zn} ; 10 \mathrm{~g} \mathrm{Cu} ; 1 \mathrm{~g} \mathrm{I} ; 200 \mathrm{mg} \mathrm{Se}$.

A total of 504 male Ross 308 chicks were used in the second trial. The chicks were raised until $29 \mathrm{~d}$ of age, as described in the general procedure, and weighed $(1130 \pm 13.6 \mathrm{~g})$. They were distributed into pens in a completely randomized design with seven treatments and four repetitions per treatment. There were 18 birds per floor pen replicate. Mortality during d 29 to 42 was recorded for each pen. Body weights of individual bird were recorded to evaluate the growth rate. On the basis of this, the cumulative body weight for each replicate was measured during days 29 to 35 and days 36 to 42 .

At 35 and 42 days of age blood was collected for serum clinical chemistry from two birds per group (eight from each replicate floor and cage) by heart puncture using vaccutainer tubes (BD Biosciences, Franklin Lakes, NJ). Blood chemistry was determined using a clinical chemistry analyser (Mabna Corporation, Karaj, Iran). The concentration of calcium and activity of alkaline phosphatase (ALP, EC 3.1.3.1) in serum were used as indicators of calcium homeostasis and bone problems (Rath et al., 2007). The 
DGKC kit method was used to measure the alkaline phosphate activity in the serum sample (Kumar et al., 2011).

Table 2 Compositions of the diets used during the experimental period (29 - 42 days of age) in trials 1 and 2

\begin{tabular}{lcccc}
\hline Foodstuff $(\mathrm{g} / \mathrm{kg})$ & Treatment $1^{*}$ & Treatment 2 & Treatment 4 & Treatment 6 \\
\hline Wheat & 363.8 & 360.5 & 359.7 & 357.9 \\
Barley & 300.0 & 300.0 & 300.0 & 300.0 \\
Soybean meal & 279.3 & 280.9 & 280.4 & 280.9 \\
Soya oil & 27.4 & 28.8 & 28.6 & 29.0 \\
Oyster shell & 12.4 & 12.5 & 12.4 & 12.4 \\
Dicalcium phosphate & 8.9 & 9.0 & 9.0 & 9.0 \\
Vitamin premix & 0.00 & 0.8 & 1.6 & 2.5 \\
Mineral premix & 2.5 & 2.5 & 2.5 & 2.5 \\
Sodium chloride & 2.8 & 2.8 & 2.8 & 2.8 \\
DL-Methionine & 1.7 & 1.8 & 1.8 & 1.8 \\
L-Lysine-HCl & 0.7 & 0.7 & 0.7 & 0.7 \\
Enzyme & 0.5 & 0.5 & 0.5 & 0.5 \\
Calculated composition & & & & \\
ME (MJ/kg) & 12.1 & 12.1 & 12.1 & 12.1 \\
Analysed CP (g/kg) & 200 & 200 & 200 & 200 \\
Met (g/kg) & 3.7 & 3.7 & 3.7 & 3.7 \\
Met + Cys (g/kg) & 7.7 & 7.7 & 7.7 & 7.7 \\
Lys (g/kg) & 9.7 & 9.7 & 9.7 & 9.7 \\
Sodium (g/kg) & 1.6 & 1.6 & 1.6 & 1.6 \\
Calcium (g/kg) & 7.6 & 7.6 & 7.6 & 7.6 \\
Phosphorus (available) $(\mathrm{g} / \mathrm{kg})$ & 3.7 & 3.7 & 3.7 & 3.7 \\
& & & &
\end{tabular}

* T1: basal diet with no vitamin premix (VP) during 29 - 42 days; T2: 33\% VP during 29 - 42 days; T4: 66\% VP during 29 - 42 days; T6: 100\% VP during 29 - 42 days.

At days 35 and 42 of age, one bird per replicate for Trial 1 and two birds of each replicate for Trial 2 were slaughtered and bone parameters were measured. The middle toe of the right leg was collected, defatted, and ashed (dry, fat-free basis) at $600{ }^{\circ} \mathrm{C}$ for $16 \mathrm{~h}$ to determine percentage ash. Total phosphorus in the samples (dry, fat-free basis) was determined using the colorimetric method. Samples were ashed and boiled in acid to dissolve all phosphorus. The concentration of phosphorus in the supernatant was determined with an analytical kit (Sigma kit \#670, Sigma Diagnostics Inc., Pars Azmoon). Calcium was determined by flame atomic absorption spectroscopy (AOAC, 2000). The biomechanical strength (the load and stress at failure, the strain, and Young's modulus; Rath et al., 2004) of the right metatarsus of individual birds was determined using a three-point flexural bending method with an Instron 4502 material testing machine (Instron Corp., Canton, MA). The mid-diaphyseal diameter of the bones at the site of impact was measured using a dial calliper (Rath et al., 1999; 2004).

Quantitative results were expressed as mean \pm SEM, analysed by GLM procedure and separated using Duncan's multiple range tests with SAS statistical software (SAS, 2002). Differences were considered significant at $P<0.05$. 


\section{Results and Discussion}

Mortality was within the expected range and there was no significant difference between treatments. The results of Trial 1 for body weight at 35 and 42 days of age are shown in Table 3. During 36 - 42 days the body weight of the broilers on the diet from which the vitamin premix was withdrawn (T1) had a lower body weight $(P<0.05)$ compared with those receiving the vitamin premix (Table 3$)$. The findings of this study differed from those reported by Khajali et al. (2006) and Alahyari-Shahrasb et al. (2011), who showed that vitamin premix withdrawal from the finisher diet of broiler chickens did not affect body weight gain. Alahyari-Shahrasb et al. (2011) also reported that the withdrawal of the vitamin premix at $29 \mathrm{~d}$ did not influence the immune system and performance of broilers. Waldroup et al. (1985) reported that the presence or absence of a commercial vitamin mix in a corn-soybean meal diet had no significant effect on body weight gain and feed utilization of broilers between 42 to 49 days of age. However, the findings of this study were comparable with those of Deyhim \& Teeter (1993), who demonstrated that broiler chickens reared in batteries under a cycling ambient temperature $\left(24{ }^{\circ} \mathrm{C}\right.$ to $35{ }^{\circ} \mathrm{C}$, creating heat stress), and fed diets without vitamin and mineral premix had a lower weight gain and poorer feed conversion than birds fed normally supplemented diets, whereas birds in cages required more dietary vitamins than those on floor housing because of more limited opportunity for coprophagy.

Table 3 Effect of reduction or withdrawn of vitamin premix (VP) on body weight (BW) and ash, and calcium $(\mathrm{Ca})$ and phosphorus $(\mathrm{P})$ content of the middle toe-bone (dry, fat-free basis; Trial 1)

\begin{tabular}{lcccccccc}
\hline & \multicolumn{4}{c}{35 days of age } \\
\cline { 2 - 9 } & $\begin{array}{c}\text { Bone ash } \\
(\mathrm{g} / 100 \mathrm{~g})\end{array}$ & $\begin{array}{c}\text { Ca } \\
(\mathrm{g} / 100 \mathrm{~g})\end{array}$ & $\begin{array}{c}\mathrm{P} \\
(\mathrm{g} / 100 \mathrm{~g})\end{array}$ & $\begin{array}{c}\text { BW } \\
(\mathrm{g})\end{array}$ & $\begin{array}{c}\text { Bone ash } \\
(\mathrm{g} / 100 \mathrm{~g})\end{array}$ & $\begin{array}{c}\text { Ca } \\
(\mathrm{g} / 100 \mathrm{~g})\end{array}$ & $\begin{array}{c}\mathrm{P} \\
(\mathrm{g} / 100 \mathrm{~g})\end{array}$ & $\begin{array}{c}\text { BW } \\
(\mathrm{g})\end{array}$ \\
\hline T 1 & $51.8 \pm 0.5$ & $19.20 \pm 1.2$ & $8.74 \pm 0.4$ & $1695 \pm 58$ & $48.2^{\mathrm{b}} \pm 1.1$ & $17.58^{\mathrm{b}} \pm 0.6$ & $8.98^{\mathrm{b}} \pm 0.04$ & $2140^{\mathrm{b}} \pm 43$ \\
T 2 & $52.3 \pm 0.6$ & $19.35 \pm 1.3$ & $8.83 \pm 0.3$ & $1678 \pm 54$ & $68.0^{\mathrm{a}} \pm 1.4$ & $25.27^{\mathrm{a}} \pm 0.5$ & $11.68^{\mathrm{a}} \pm 0.2$ & $2332^{\mathrm{a}} \pm 41$ \\
T 3 & $50.0 \pm 0.5$ & $18.52 \pm 1.4$ & $8.49 \pm 0.6$ & $1684 \pm 61$ & $68.2^{\mathrm{a}} \pm 1.6$ & $25.24^{\mathrm{a}} \pm 0.5$ & $11.75^{\mathrm{a}} \pm 0.1$ & $2362^{\mathrm{a}} \pm 36$ \\
T 4 & $55.2 \pm 0.4$ & $20.42 \pm 1.3$ & $9.38 \pm 0.3$ & $1691 \pm 57$ & $67.5^{\mathrm{a}} \pm 1.9$ & $24.96^{\mathrm{a}} \pm 0.6$ & $11.52^{\mathrm{a}} \pm 0.2$ & $2354^{\mathrm{a}} \pm 48$ \\
T 5 & $54.3 \pm 0.5$ & $20.03 \pm 1.3$ & $9.23 \pm 0.3$ & $1692 \pm 52$ & $68.6^{\mathrm{a}} \pm 1.7$ & $25.51^{\mathrm{a}} \pm 0.6$ & $11.84^{\mathrm{a}} \pm 0.3$ & $2370^{\mathrm{a}} \pm 52$ \\
T 6 & $55.9 \pm 0.7$ & $20.60 \pm 1.4$ & $9.36 \pm 0.4$ & $1692 \pm 64$ & $69.6^{\mathrm{a}} \pm 1.9$ & $26.01^{\mathrm{a}} \pm 0.8$ & $11.93^{\mathrm{a}} \pm 0.4$ & $2377^{\mathrm{a}} \pm 42$ \\
T 7 & $56.6 \pm 0.8$ & $20.87 \pm 1.3$ & $9.57 \pm 0.5$ & $1684 \pm 48$ & $68.7^{\mathrm{a}} \pm 1.6$ & $25.43^{\mathrm{a}} \pm 0.5$ & $11.96^{\mathrm{a}} \pm 0.3$ & $2363^{\mathrm{a}} \pm 54$
\end{tabular}

\footnotetext{
${ }^{\mathrm{a}, \mathrm{b}}$ Means within columns with different superscripts denote significant differences $(P<0.05)$.

Treatments: T1: the basal diet with no vitamin premix (VP) during at 29 - 42 days; T2: 33\% VP during 29 - 42 days; T4: 66\% VP during 29 - 42 days; T6: 100\% VP during 29 - 42 days.

Up to 35 days, treatments 3,5 and 7 were similar to treatments 2,4 and 6 , respectively, but at 36 days of age the vitamin premix was withdrawn.
}

The results from Trial 2 for body weight are shown in Table 5. A reduction or withdrawn of the vitamin premix at different ages did not significantly affect body weight $(P>0.05)$. Findings of this study in Trial 2 were similar to those reported by Skinner et al. (1992), Khajali et al. (2006) and Alahyari-Shahrasb et al. (2011), who showed that vitamin and mineral premix withdrawal from the finisher diet of broiler chickens did not affect body weight gain. Skinner et al. (1992) suggested that the absence of a withdrawal effect could be related to the availability in the body of vitamins and minerals for further growth, as the amounts of these supplements usually exceed by two or three times the recommended broiler chicken requirement in poultry diets. In contrast, omitting vitamins from the finisher diet for the same removal period decreased weight gain in three broiler strains (Patel et al., 1997; Maiorka et al., 2002). These differences may be owing to the type of rearing system (floor litter or cages) or differences in diet composition. Maiorka et al. (2002) suggested that withdrawal of the vitamin mix during the final period of chicken growth is more deleterious than withdrawal of the mineral mix, because of its effect on the feed conversion ratio (FCR). However, carcass yield was not affected by withdrawal of the vitamin or mineral mix. 
Table 4 Bone parameters and blood chemistry of birds fed different vitamin premix (Trial 1)

\begin{tabular}{|c|c|c|c|c|c|c|c|c|}
\hline & \multicolumn{4}{|c|}{35 days of age } & \multicolumn{4}{|c|}{42 days of age } \\
\hline & $\begin{array}{c}\text { Load @ yield } \\
\qquad(\mathrm{kg} \\
\left.\text { force } / \mathrm{mm}^{2}\right)\end{array}$ & $\begin{array}{l}\text { Young's } \\
\text { modulus } \\
\left(\mathrm{kg} / \mathrm{mm}^{2}\right)\end{array}$ & $\begin{array}{c}\text { ALP* } \\
\left(10^{3} \mathrm{U} / \mathrm{L}\right)\end{array}$ & $\begin{array}{c}\text { Blood Ca } \\
(\mathrm{mg} / \mathrm{dL})\end{array}$ & $\begin{array}{c}\text { Load @ } \\
\text { yield } \\
(\mathrm{kg} \\
\left.\text { force } / \mathrm{mm}^{2}\right)\end{array}$ & $\begin{array}{l}\text { Young's } \\
\text { modulus } \\
\left(\mathrm{kg} / \mathrm{mm}^{2}\right)\end{array}$ & $\begin{array}{c}\text { ALP } \\
\left(10^{3} \mathrm{U} / \mathrm{L}\right)\end{array}$ & $\begin{array}{c}\text { Blood Ca } \\
(\mathrm{mg} / \mathrm{dL})\end{array}$ \\
\hline T 1 & $5.06 \pm 0.46$ & $139.6 \pm 8.4$ & $35.2^{\mathrm{b}} \pm 3.7$ & $8.8 \pm 0.2$ & $5.07^{\mathrm{b}} \pm 0.44$ & $130.1^{\mathrm{b}} \pm 11.9$ & $76.1^{b} \pm 6.2$ & $9.9^{\mathrm{b}} \pm 0.3$ \\
\hline Т 2 & $5.27 \pm 0.42$ & $146.7 \pm 9.2$ & $23.2^{\mathrm{a}} \pm 2.1$ & $9.2 \pm 0.3$ & $6.25^{\mathrm{ab}} \pm 0.37$ & $234.7^{\mathrm{a}} \pm 13.2$ & $30.2^{\mathrm{a}} \pm 3.7$ & $10.3^{\mathrm{ab}} \pm 0.5$ \\
\hline Т 3 & $5.55 \pm 0.40$ & $149.5 \pm 8.1$ & $21.5^{\mathrm{a}} \pm 2.3$ & $9.1 \pm 0.2$ & $6.50^{\mathrm{ab}} \pm 0.41$ & $235.2^{\mathrm{a}} \pm 16.3$ & $30.4^{\mathrm{a}} \pm 3.8$ & $10.4^{\mathrm{ab}} \pm 0.5$ \\
\hline $\mathrm{T} 4$ & $5.66 \pm 0.47$ & $165.4 \pm 10.2$ & $20.6^{\mathrm{a}} \pm 1.9$ & $9.3 \pm 0.4$ & $7.42^{\mathrm{a}} \pm 0.35$ & $237.1^{\mathrm{a}} \pm 14.5$ & $28.1^{\mathrm{a}} \pm 3.9$ & $11.0^{\mathrm{a}} \pm 0.4$ \\
\hline T 5 & $6.10 \pm 0.52$ & $154.6 \pm 9.4$ & $20.5^{\mathrm{a}} \pm 2.0$ & $9.2 \pm 0.2$ & $7.36^{\mathrm{a}} \pm 0.38$ & $232.9^{\mathrm{a}} \pm 13.8$ & $26.1^{\mathrm{a}} \pm 3.5$ & $10.8^{\mathrm{a}} \pm 0.3$ \\
\hline T 6 & $5.77 \pm 4.9$ & $166.0 \pm 10.5$ & $20.1^{\mathrm{a}} \pm 1.9$ & $9.3 \pm 0.3$ & $7.03^{\mathrm{a}} \pm 0.35$ & $245.1^{\mathrm{a}} \pm 14.7$ & $28.6^{\mathrm{a}} \pm 3.9$ & $11.0^{\mathrm{a}} \pm 0.3$ \\
\hline $\mathrm{T} 7$ & $6.17 \pm 0.57$ & $160.1 \pm 10.7$ & $20.1^{\mathrm{a}} \pm 2.0$ & $9.3 \pm 0.2$ & $7.43^{\mathrm{a}} \pm 0.43$ & $243.5^{\mathrm{a}} \pm 13.9$ & $26.0^{\mathrm{a}} \pm 3.7$ & $10.9^{\mathrm{a}} \pm 0.2$ \\
\hline
\end{tabular}

\footnotetext{
${ }^{\mathrm{a}, \mathrm{b}}$ Means within columns with different superscripts denote significant differences $(P<0.05)$.

Treatments: T1: the basal diet with no vitamin premix (VP) during at 29 - 42 days; T2: 33\% VP during 29 - 42 days; T4: $66 \%$ VP during at 29 - 42 days; T6: $100 \%$ VP during at 29 - 42 days.

Up to 35 days, treatments 3,5 and 7 were similar to treatments 2,4 and 6, respectively, but at 36 days of age the vitamin premix was withdrawn.

*ALP - alkaline phosphatase.
}

The removal of the vitamin premix from broiler diets does not imply that such diets are void of these essential nutrients. Unfortified diets, especially those that include some animal protein feedstuff, may contain sufficient quantities of vitamins to meet or exceed minimum recommended needs. Vitamin premixes used in the commercial broiler industry typically provide vitamin premix at two- to fourfold or more of the minimum recommended levels (Gwyther et al., 1992); thus, some storage within the carcass should be expected, especially for the fat-soluble vitamins. Under commercial growing conditions, using practical feedstuffs, it may be difficult to produce vitamin premix deficiencies in birds during the finishing period following adequate supplementation early in the growing period. Reduction of these supplements in diets fed from 29 to 42 days of age could significantly reduce growing costs with no adverse effects on performance.

The effects of different levels of vitamin premix on bone strength, and the concentration of ash, Ca and $\mathrm{P}$ of bone and serum concentrations of $\mathrm{Ca}$ and ALP, in trials 1 and 2 are shown in Tables 3, 4, 5 and 6. Bone morphometric and mechanical parameters have been used as indicator of bone status in nutritional and genetic research of poultry (Rath et al., 2000; 2007). There is little information about bone quality when the vitamin premix was withdrawn or reduced in the diet of broiler chickens. Vitamin D has a major regulatory role in bone metabolism and bone strength (NRC, 1994). The results of Trial 1 showed that there were no significant differences in strength of the metatarsus bone and the contents of ash, $\mathrm{Ca}$ and $\mathrm{P}$ in the toe with reduction or withdrawal of vitamin premix from diets during days 29 - 35. Findings of this study in Trial 1 were similar to those reported by Christmas et al. (1995), who showed that vitamin and mineral premix withdrawal from the finisher diet of broiler chickens did not affect leg abnormalities. However, there were significant differences between the treatment without vitamin premix (T1) and other treatments for these parameters except serum $\mathrm{Ca}$ concentration at $36-42$ days of age $(P<0.05)$. Furthermore, significant differences were observed for Ca concentration of T1 and T4, T5, T6 and T7 at $36-42$ days $(P<0.05)$.

It seems that birds in cages require more dietary vitamins because of more limited opportunity for coprophagy. Cantor et al. (1980) studied the usefulness of bone densitometry as an indicator of vitamin D status in turkey poults. The correlation coefficient between dietary vitamin $\mathrm{D}$ and bone mineral mass was 0.80 , and between vitamin $\mathrm{D}$ and percentage bone ash was 0.78 . The correlation coefficient between bone mineral mass and bone ash was 0.71 . They concluded that bone densitometry was as good an indicator as 
Table 5 Effect of reduction or withdrawn of vitamin premix on body weight (BW) and ash, and calcium (Ca) and phosphorus $(\mathrm{P})$ content of the middle toe-bone (dry, fat-free basis; Trial 2)

\begin{tabular}{ccccccccc}
\hline & & $\begin{array}{c}\text { 35 days of } \\
\text { age }\end{array}$ & $\begin{array}{c}\text { 42 days } \\
\text { of age }\end{array}$ & $\begin{array}{c}\text { BW } \\
(\mathrm{g})\end{array}$ & $\begin{array}{c}\text { Bone ash } \\
(\mathrm{g} / 100 \mathrm{~g})\end{array}$ & $\begin{array}{c}\text { Ca } \\
(\mathrm{g} / 100 \mathrm{~g})\end{array}$ & $\begin{array}{c}\text { P } \\
(\mathrm{g} / 100 \mathrm{~g})\end{array}$ & $\begin{array}{c}\text { BW } \\
(\mathrm{g})\end{array}$ \\
\hline T 1 & $53.4 \pm 0.08$ & $19.68 \pm 0.7$ & $8.83 \pm 0.6$ & $1725 \pm 67$ & $64.5 \pm 3.4$ & $24.15 \pm 2.2$ & $11.12 \pm 1.2$ & $2365 \pm 43$ \\
T 2 & $54.5 \pm 0.07$ & $20.23 \pm 0.3$ & $9.27 \pm 0.3$ & $1740 \pm 51$ & $66.8 \pm 2.4$ & $24.41 \pm 2.2$ & $11.31 \pm 1.3$ & $2361 \pm 32$ \\
T 3 & $54.7 \pm 0.06$ & $20.36 \pm 0.5$ & $9.30 \pm 0.5$ & $1785 \pm 32$ & $66.6 \pm 2.8$ & $24.26 \pm 2.4$ & $11.26 \pm 1.3$ & $2390 \pm 36$ \\
T 4 & $53.9 \pm 0.08$ & $19.71 \pm 0.6$ & $8.91 \pm 0.5$ & $1722 \pm 45$ & $69.2 \pm 3.7$ & $27.75 \pm 2.2$ & $12.07 \pm 1.4$ & $2394 \pm 43$ \\
T 5 & $54.9 \pm 0.1$ & $20.49 \pm 0.4$ & $9.45 \pm 0.4$ & $1738 \pm 48$ & $68.2 \pm 2.4$ & $26.45 \pm 2.2$ & $12.00 \pm 1.2$ & $2393 \pm 44$ \\
T 6 & $55.2 \pm 0.1$ & $20.85 \pm 0.8$ & $9.81 \pm 0.5$ & $1740 \pm 42$ & $69.3 \pm 3.2$ & $27.83 \pm 2.3$ & $12.19 \pm 1.4$ & $2395 \pm 37$ \\
T 7 & $54.8 \pm 0.08$ & $20.39 \pm 0.5$ & $9.32 \pm 0.4$ & $1742 \pm 58$ & $69.7 \pm 3.4$ & $28.00 \pm 2.3$ & $12.27 \pm 1.4$ & $2391 \pm 29$
\end{tabular}

Treatments: T1: the basal diet with no vitamin premix (VP) during at 29 - 42 days; T2: 33\% VP during 29 - 42 days; T4: $66 \%$ VP during at 29 - 42 days; T6: $100 \%$ VP during at 29 - 42 days.

Up to 35 days, treatments 3,5 and 7 were similar to treatments 2,4 and 6 , respectively, but at 36 days of age the vitamin premix was withdrawn.

Treatment means within columns were not significantly different $(P>0.05)$.

Table 6 Bone parameters and blood chemistry of birds fed different vitamin premix (Trial 2)

\begin{tabular}{|c|c|c|c|c|c|c|c|c|}
\hline & \multicolumn{4}{|c|}{35 days of age } & \multicolumn{4}{|c|}{42 days of age } \\
\hline & $\begin{array}{c}\text { Load @ } \\
\text { yield } \\
(\mathrm{kg} \\
\left.\text { force } / \mathrm{mm}^{2}\right)\end{array}$ & $\begin{array}{l}\text { Young's } \\
\text { modulus } \\
\left(\mathrm{kg} / \mathrm{mm}^{2}\right)\end{array}$ & $\begin{array}{c}\text { ALP* } \\
\left(10^{3} \mathrm{U} / \mathrm{L}\right)\end{array}$ & $\begin{array}{c}\text { Blood Ca } \\
(\mathrm{mg} / \mathrm{dL})\end{array}$ & $\begin{array}{c}\text { Load @ } \\
\text { yield } \\
(\mathrm{kg} \\
\left.\text { force } / \mathrm{mm}^{2}\right)\end{array}$ & $\begin{array}{l}\text { Young's } \\
\text { modulus } \\
\left(\mathrm{kg} / \mathrm{mm}^{2}\right)\end{array}$ & $\begin{array}{l}\operatorname{ALP}\left(10^{3}\right. \\
\mathrm{U} / \mathrm{L})\end{array}$ & $\begin{array}{c}\text { Blood Ca } \\
(\mathrm{mg} / \mathrm{dL})\end{array}$ \\
\hline $\mathrm{T} 1$ & $4.9 \pm 0.2$ & $136.7 \pm 3.2$ & $21.6 \pm 1.8$ & $9.14 \pm 0.21$ & $5.7 \pm 0.4$ & $189.7 \pm 4.2$ & $29.2 \pm 2.2$ & $10.1 \pm 0.2$ \\
\hline Т 2 & $5.2 \pm 0.1$ & $139.1 \pm 4.2$ & $20.6 \pm 1.2$ & $9.21 \pm 0.11$ & $6.1 \pm 0.3$ & $191.2 \pm 3.4$ & $27.3 \pm 1.2$ & $10.3 \pm 0.1$ \\
\hline T 3 & $5.1 \pm 0.2$ & $137.0 \pm 2.4$ & $21.2 \pm 1.4$ & $9.18 \pm 0.21$ & $6.2 \pm 0.2$ & $192.8 \pm 4.7$ & $25.2 \pm 3.2$ & $10.3 \pm 0.2$ \\
\hline $\mathrm{T} 4$ & $5.3 \pm 0.2$ & $139.3 \pm 2.4$ & $20.1 \pm 1.1$ & $9.22 \pm 0.23$ & $6.6 \pm 0.6$ & $198.6 \pm 6.3$ & $28.6 \pm 2.1$ & $10.6 \pm 0.4$ \\
\hline T 5 & $5.2 \pm 0.1$ & $141.2 \pm 4.2$ & $19.4 \pm 1.4$ & $9.19 \pm 0.12$ & $6.5 \pm 0.4$ & $196.6 \pm 4.7$ & $28.5 \pm 1.2$ & $10.4 \pm 0.2$ \\
\hline T 6 & $5.4 \pm 0.3$ & $142.1 \pm 5.1$ & $19.1 \pm 1.2$ & $9.25 \pm 0.14$ & $6.7 \pm 0.6$ & $197.5 \pm 4.2$ & $25.4 \pm 2.1$ & $10.6 \pm 0.3$ \\
\hline $\mathrm{T} 7$ & $5.3 \pm 0.2$ & $141.8 \pm 4.2$ & $19.9 \pm 1.4$ & $9.20 \pm 0.9$ & $6.4 \pm 0.2$ & $196.9 \pm 5.7$ & $25.6 \pm 2.4$ & $10.6 \pm 0.4$ \\
\hline
\end{tabular}

Treatments: T1: the basal diet with no vitamin premix (VP) during at 29 - 42 days; T2: 33\% VP during 29 - 42 days; T4: 66\% VP during at 29 - 42 days; T6: 100\% VP during at 29 - 42 days.

Up to 35 days, treatments 3,5 and 7 were similar to treatments 2,4 and 6, respectively, but at 36 days of age the vitamin premix was withdrawn.

Treatment means within columns were not significantly different $(P>0.05)$.

*ALP - alkaline phosphatase.

bone ash for the vitamin D status in turkey poults. There were significant differences between $\mathrm{T} 1$ and the other treatments for ALP activity at 29 - 35 and 36 - 42 days of age. Several methods have been used to assess vitamin D nutritional status of individuals. Poor production rates in livestock, as well as bone abnormalities in animals and humans, are the chief indicators that vitamin D deficiency is substantially advanced. Low-serum Ca levels in the range of 5 to $7 \mathrm{mg} / 100 \mathrm{~mL}$ and high-serum ALP activity were used as indicators of bone problems (Rath et al., 2004). Besides vitamin D, vitamins $\mathrm{B}_{6}, \mathrm{C}$, and $\mathrm{K}$ are integral to bone health because of their involvement in the synthesis of matrix constituents, such as collagen and osteocalcin, and formation of collagen cross-links (Rath et al., 2004). Vitamin $\mathrm{B}_{6}$ (pyridoxine) deficiency affects collagen cross-links and mechanical properties of bones (Masse et al., 1996). The results of Trial 2 showed that a vitamin premix reduction and withdrawal at $29 \mathrm{~d}$ of age did not impair bone strength or 
concentrations of ash, $\mathrm{Ca}, \mathrm{P}$ of bone and blood ALP activity and $\mathrm{Ca}$ during the final period of broiler chicken $(P>0.05)$. The persistence of vitamin $\mathrm{D}$ in animals during periods of vitamin $\mathrm{D}$ deficiency may be explained by the slow turnover rate of vitamin D in certain tissues, such as the skin and adipose tissue. During deprivation, vitamin $\mathrm{D}$ in these tissues is released slowly, thus meeting the vitamin $\mathrm{D}$ needs of the animal over a longer period (McDowell, 2000). Also, vitamin D can be stored in adipose tissue, liver with a discharge storage time of 14 days. It appears that the above reasons and access of the broilers in a floor system to faeces (coprophagia) can counter a vitamin D deficiency. It seems there are some reasons that may remove or reduce the usage of vitamin supplementation (an expensive essential nutrient in poultry diets) in finisher period diets in the cage battery and floor systems, for instance i) the amount of vitamin supplements usually exceeds two or three times the recommended broiler chicken requirement in poultry diets; ii) fatsoluble vitamins may be stored by a bird in its liver and fatty tissue in sufficient quantities to meet requirements for 15 days or even longer; iii) there are some vitamins in diet ingredients such as wheat, barley and soybean meal that are not considered when formulating diets; iv) floor-raised broilers can access their faeces to ingest some vitamins which are evacuated from the intestines.

\section{Conclusions}

The results of the present study indicated that in the battery cage system it is possible to reduce the dietary vitamin premix during the finisher period, but withdrawal can negatively affect performance, ALP activity in blood and mechanical parameters of bone of broiler chickens. On the other hand, in the floor system it is possible to withdraw vitamin supplements in broiler finisher diets.

\section{Reference}

Alahyari-Shahrab, M., Moravej, H., Shivazad, M. \& Grami, A., 2011. Study of possible reduction or withdrawal of vitamin premix during finisher period in floor and battery cage broiler raising systems. Afr. J. Bio. 33, 6337-6341.

AOAC, 2000. Official methods of analysis (18th ed.). Association of Official Analytical Chemists, Inc., Arlington, Virginia, USA.

Cantor, A.H., Musser, M.A., Bacon, W.L. \& Hellelwell, A.B., 1980. The use of bone mineral mass as an indicator of vitamin D status in turkeys. Poult. Sci. 59, 563-568.

Christmas, R.B., Harms, R.H. \& Sloani, D.R., 1995. The absence of vitamins and trace minerals and broiler performance. J. Appl. Poult. Res. 4, 407-410.

Deyhim, F. \& Teeter, R.G., 1993. Dietary vitamin and/or trace mineral premix effects on performance, humoral mediated immunity and carcass composition of broilers during thermoneutral and high ambient temperature distress. J. Appl. Poult. Res. 2, 347-355.

Gwyther, M.J., Tillman, P.B., Frye, T.M. \& Lentz, E.L., 1992. Comparison of 2 levels of vitamin supplementation for broilers. Poult. Sci. 71, 153-159.

Khajali, F., Asadi Khoshoei, E. \& Zamani, M., 2006. Effect of vitamin and trace mineral withdrawal from finisher diets on growth performance and immunocompetence of broiler chickens. Br. Poult. Sci. 47, 159-162.

Kumar, J., Kumar, S.S. \& Pradhan, R.K., 2011. Studies on excessive daytime sleepiness (EDS) and alkaline phosphatase activity in smoker and alcoholic person. Wrld J. Sci. Technol. 4, 33-38.

Maiorka, A., Laurentiz, A.C., Santin, E., Araujo, L.F. \& Macari, M., 2002. Dietary vitamin or mineral mix removal during the finisher period on broiler chicken performance. J. Appl. Poult. Res. 11, 121-126.

Masse, P.G., Rimnack, C.M., Yamauchi, M., Coburn, S.P., Rucker, R.B., Howell, D.S. \& Boskey, A.L., 1996. Pyridoxine deficiency affects biomechanical properties of chick tibial bones. Bone 18, 567-574.

McDowell, L.R., 2000. Vitamins in Animal Nutrition. In: Comparative Aspects to Human Nutrition. Ed. McDowell, L.R., Lowa State University Academic Press, London, UK. pp. 91-153.

NRC, 1994. Nutrient Requirements of Poultry (9th ed.). National Research Council, National Academy Press, Washington D.C., USA.

Ogunwole, O.A., Kolade, E.O., Olumide, M.O., Akinsoyinu., A.O., Mako, A.A., Abiola- Olagunju, O. \& Adebiyi, O.A., 2011. Evaluation of five proprietary vitamin-mineral premixes in Ibadan, Nigeria for broiler production. Poultry Science Association (PSA) at the annual AAAP/AVMA meeting in St. Louis, MO. pp. 83. 
Olfert, D. Cross, B.M. \& McWilliam, A.A., 1993. Guide to the care and use of experimental animals. Canadian Council on Animal Care, 1993. Volume 1. E., CCAC, Ottawa, ON, Canada.

Patel, K.P., Edwards, H.M. \& Baker, D.H., 1997. Removal of vitamin and trace mineral supplements from broiler finisher diets. J. Appl. Poult. Res. 6, 191-198.

Rath, N.C., Balog, J.M., Huff, W.E., Huff, G.R., Kulkarni, G.B. \& Tierce, J.F., 1999. Comparative differences in the composition and biomechanical properties of tibiae of seven- and seventy-twoweek-old male and female broiler breeder chickens. Poult. Sci. 78, 1232-1239.

Rath, N.C., Huff, G.R., Huff, W.E. \& Balog, J.M., 2000. Factors regulating bone maturity and strength in poultry. Poult. Sci. 79, 1024-1032.

Rath, N.C., Huff, W.E., Balog, J.M. \& Huff, G.R., 2004. Comparative efficacy of different dithiocarbamates to induce tibial dyschondroplasia in poultry. Poult. Sci. 83, 266-274.

Rath, N.C., Kannan, L., Pillai, P.B., Huff, W.E., Huff, G.R., Horst, R.L. \& Emmert, J.L., 2007. Evaluation of the efficacy of vitamin $\mathrm{D}_{3}$ or its metabolites on thiram-induced tibial dyschondroplasia in chickens. Res. Vet. Sci. 83, 244-250.

SAS, 2002. Statistical Analysis Systems user's guide (5th ed.). SAS Institute Inc., Raleigh, North Carolina, USA.

Skinner, J.T., Waldroup, A.L. \& Waldroup, P.W., 1992. Effects of removal of vitamin and trace mineral supplements from grower and finisher diets on live performance and carcass composition of broilers. J. Appl. Poult. Res. 1, 280-286.

Waldroup, P.W., HeUwlg, H.M., Spencer, G.K., Smith, N.K., Fancher, B.I., Jackson, M.E., Johnson, Z.E. \& Goodwin, T.L., 1985. The effects of increased levels of niacin supplementation on growth rate and carcass composition of broiler chickens. Poult. Sci. 64, 1777-1783.

Weber, P., 1999. The role of vitamins in the prevention of osteoporosis. A brief status report. Int. J. Vitam. Nutr. Res. 69, 194-197. 